\title{
Model Of Policy Implementation Of Billboard Arrangement That Can Be Increase The Pad Of Pekanbaru City
}

\author{
Hernimawati ${ }^{1}$, Trio Saputra \\ ${ }^{1}$ Universitas Lancang Kuning, Pekanbaru, Indonesia
}

\begin{abstract}
This research is based on the principal issues concerning the billboard planning policy which has not been optimally be able to improve the Local Revenue of Pekanbaru City and has not improved the beauty of Pekanbaru City. It was estimated to be caused by the model of the billboard planning policy can not increase PAD through billboard tax receipts as well as to enhance the visual beauty of Pekanbaru City. The method used in this research is descriptive qualitative, which aims to establish model of billboard planning policy implementation which be able to improve the PAD of Pekanbaru City. The research result indicated that the model of billboard planning policy implementation which be able to improve the PAD of Pekanbaru City mandated the Regional Revenue Office of Pekanbaru City as the responsible agency for organizing and billboard planning in Pekanbaru City. Regarding the supervision and control, the Regional Revenue Office of Pekanbaru City coordinate with the Municipal Police of Pekanbaru City who are conducting surveillance and control in the field up to dismantling of billboard that violate the rules.
\end{abstract}

Keywords: Billboard, Policy, Model.

\section{INTRODUCTION}

The complexity of the activities related to trade in goods and services resulting in the promotion competition increasingly crowded so that the need for a media campaign become a vital necessity on an area of trade in goods and services. The increased competition in the trade, trigger the appearance of private sign ie commercial messages in the form of billboards. According to Danisworo ${ }^{2}$ (2013: 113) placement of billboards strategically and well ordered be able to provide opportunities for the public to get a good visual access on the information resources. The existence of various forms of billboards, size, and striking color will be interesting when seen at a certain distance. If that media designed to be intuitive by structuring the beautiful lights will more enliven the face of the city at night. The billboard will provide colorful illumination for a city park and the road around it. Pekanbaru City public expectations, billboard placement which is well organized will be more beautifying and embellish the spatial planning of Pekanbaru City.
But in reality, the Pekanbaru City public expectations do not conform to what happened in the field. Facts in the field showed the presence of billboards in Pekanbaru City do not well organized. This arrangement of billboards which are not well organized add clutter which tends to spoil the view the city faces. Billboards grow like mushrooms in the rainy season, Pekanbaru City currently become a jungle of billboard. The safety aspect in the installation of billboards tend to be neglected. The commercial aspect or business aspects far more dominant and more important rather than beauty and security aspects. Those condition is driven by reality that the billboard tax is one potential source of local revenue, so that local governments need to do optimization.

Billboard planning policy in Pekanbaru City stated in Pekanbaru Mayor Regulation No. 24 Year 2013 on the Implementation of Building Billboards in the Pekanbaru City (hereinafter referred Perwali of Billboard of Pekanbaru City). This Perwali of Billboard of Pekanbaru City arrange of objects and subjects of the taxpayer, imposition and tax rates based billboard building, procedures for the collection and calculation of the billboard tax, surveillance, provision of inspection and 
sanctions both administrative sanctions and criminal sanctions.

Although the billboard tax provisions in Pekanbaru City already regulated in the Perwali of Billboard of Pekanbaru City above mentioned, but the realization of this the billboard tax has not been in line with expectations of Pekanbaru City Government. The billboard tax acceptance of Pekanbaru City which has not been optimal, naturally affect the Regional Revenue (PAD) of Pekanbaru City. Whereas the Pekanbaru City Government have an expectation that the billboard tax is one of the programs to increase the PAD of Pekanbaru City. This means that the billboard policy implementation of Pekanbaru City which is regulated in Perwali of Billboard of Pekanbaru City has not been implemented optimally.

The study was inspired by studies such as research by Zulkarnain Umar, et. al., (2015) and research by Azad and Boushehri (2014). Research by Zulkarnain Umar, et. al., (2015) had found model of policy implementation of Kuala Lumpur City Government towards billboard location arrangement related with the billboard tax revenue. While the research by Azad and Boushehri (2014) formulate a model of the billboard arrangement which can be useful for the government to control the billboard bound. Besides this study also refer to research by Muhharia (2012) which describes the model of the implementation process of Pontianak Mayor regulations, which includes the licensing phase, placement stage location as well as the duration and controlling stages.

This study is based on the principal issues concerning the billboard planning policy which has not been optimally be able to improve the Local Revenue of Pekanbaru City and has not improved the beauty of Pekanbaru City. It was estimated to be caused by the model of the billboard planning policy can not increase PAD through billboard tax receipts as well as to enhance the visual beauty of Pekanbaru City.

\section{RESEARCH METHOD}

The research method used in this research is descriptive qualitative research method. Qualitativedescriptive research is research conducted to describe in detail a particular social phenomenon without using a hypothesis that has been formulated strictly (Singarimbun, 2002: 4). Moleong stated that the method of qualitative research is defined as research that produces descriptive data in the form of words written or spoken of people and observed behavior (Moleong, 2010: 36). While descriptive study aimed to describe the complex social reality by applying the concepts that have been developed (Vredenberght, 2010: 45).

In this study, researchers intend to describe the advertisement tax receipts in the city of Pekanbaru is not optimal. Ketidakoptimalan is caused by a large billboard wild / illegal who do not pay taxes. In fact, the actual tax of this billboard can be used to increase revenue (PAD). Therefore, the research selected by the researchers is a descriptive study (descriptive word meaning: describe or explain). Qualitative research methods used in this study with the reasons for the problem under study are complex, dynamic and full of meaning that could not have data on the social situation are complex, dynamic and uncertain that the problem captured by quantitative research methods. In addition the use of this method the researchers intended to understand in depth the issue of structuring advertisement semawrut in Pekanbaru city associated with Improvement Program (PAD).

\section{Data Collection Techniques}

Data collection techniques rely to interview, observation and documentation. The applicability of these three methods of data collection considering that the phenomenon is different from the abstract concrete. The phenomenon of concrete only be understood as it is, a work produced under certain conditions.

a. Depth Interviews(IndepthInteview)

interviews a data collection tools or information, by asking a number of questions to be answered orally orally also by the respondent (Maman, 2010: 73).

b. Observations

According Indriantoro and Supomo (2012: 157) observation is the process of recording the subject's behavior pattern (people), the object (object) or systematic occurrence without any questions or communication with the individuals studied. Using this technique, the authors observe and see firsthand the situation and condition rather than objects and sites. Generally in this observation techniques the author uses to conduct preliminary studies that are reviewed, recognize and identify the problems examined.

c. Documentation

Documentation of data collection in which researchers investigate written objects such as books, magazines, documents, regulations, and so on (Arikunto, 2010: 158).

\section{Data Analysis}

The process of data analysis is qualitative form a cycle with data analysis by Miles and Huberman (1992: 20), namely:

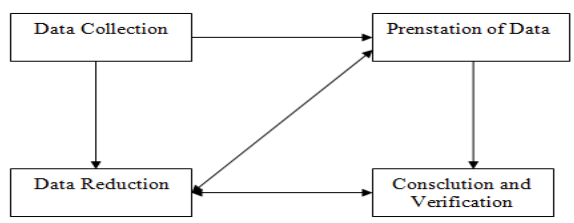

Figure 1 Qualitative Data Analysis Techniques (Miles and Huberman, 1992: 20)

Miles and Huberman (1992: 20) mentions that activity in qualitative data analysis performed interactively and continues over time(cyclicalprocess)at every stage of research, through to completion, and saturated. Activities conducted in this analysis is the collection of data(data collection), the reduction of the 
data(datareduction), exposure (data display) , and the conclusion or verification(conclusion/verification). The collection of data(datacolection), on these investigators collect all the notes, photos of activities, recorded interviews, written documents, from the observation and interviews, then sorted according the problem and arranged in order of time of data collection activities. Reduction of data(datareduction), in this activity the researchers conducted a data reduction of the amount of data that is still common and complex to be chosen where the principal / relevant, focused on things that are important, look for a theme or a pattern that deserves to be presented (Nasution, 2010 ). Data reduction can be done in various ways, namely by careful selection, with a summary, a description of the sentence, taking into account the importance of data and a moderate degree of data. Exposure to the data(datadisplay), the activities carried out are arranging or composing, organizing data into new information that can be retrieved at the whole picture, as a conclusion or action. Exposure to good data and are often used in the form of narrative text, a wide variety of matrices, images graphics, networks and charts ;Conclusion/verification of data(conclusion/verification)is the principal activity in the data analysis, namely the inductive process that does not ignore the validity of such principles, the ability for authenticated, reasonable, measurable, and firmness.

The data is more meaningful in sentences of the form of numbers, and this data can be collected through interviews, observation, documentation and others, all of which can be processed, edited and transcribed into a final conclusion. Taking into account a variety of factors, especially on issues related to technical and other requirements, the data analysis techniques to be used in this study were taking the approach developed by Miles and Huberman (1992: 20).

\section{FINDINGS AND DISCUSSION}

In this study constructed a thinking framework concerning the efforts to increase the Regional Revenue (PAD) through the arrangement of billboard policy model in Pekanbaru City based on the though of theoritical study. The theory used in this study were Public Administration Theory of Pfiffner and Presthus (2010: 5) as Grand Theory, Public Policy Theory of Parker (2012: 37) as Middle Range Theory and Public Policy Implementation Theory of Van Meter and Van Horn actualized by Imamura $^{3}$ (2015: 14-15) as Applied Theory, which can be illustrated as follows:

\section{Figure 2 Theoritical Framework}

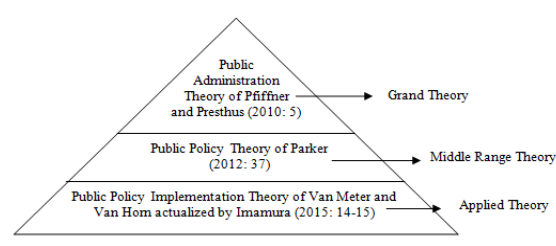

In addition the above theory, this study also uses the concept of Local Revenue (PAD) and Reklame concept to be used as an analytical tool in answering the formulation of research problems.

Referring to the results of benchmarking with Batam City and Rokan Hilir Regency, be ableto note the difference of the arrangement of Billboard in Batam City, Pekanbaru City and Rokan Hilir Regency such as in Batam City, targets and policy objectives are prioritized on the aspects of beauty arrangement of the city, while in Pekanbaru City intended for the arrangement of billboard and the billboard tax increase which will contribute to PAD of Pekanbaru City. Meanwhile the Local Regulation of Rokan Hilir Regency more focused on increasing the billboard tax.

Based on the benchmarking results as mentioned above then the visually of billboard arrangement model which can be increase of PAD of Pekanbaru City can be illustrated as follows:

\section{Figure 3: Billboard Arrangement Model which can be Increase of PAD of Pekanbaru City}

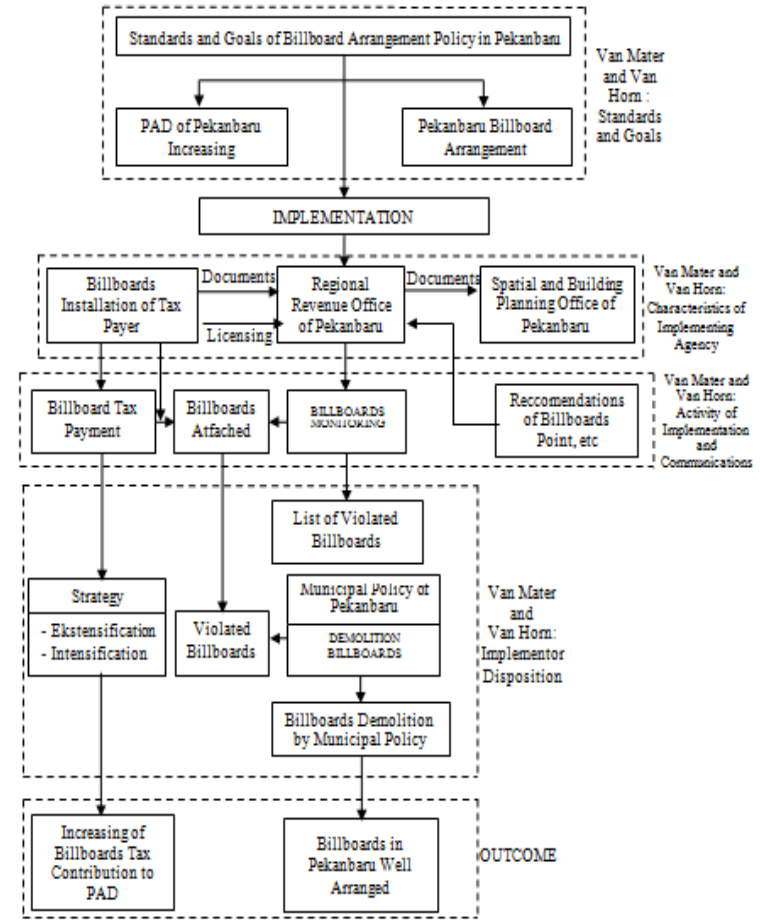

The above model is an integration between the factors of the Van Meter and Van Horn model which captured standards and policy objectives factor, the implementing agency characteristics, implementation activities and communications and the executor/ implementor disposition as well as the benchmarking results with Batam City and Rokan Hilir Regency.

From the model illustrated above, the responsible agency on the billboards arrangement in Pekanbaru City mandated to Regional Revenue Office of Pekanbaru City. The authority of Regional Revenue Office of Pekanbaru City started from licensing, billboard tax receipts, surveillance to enforcement. In terms of licensing, the Regional Revenue Office of Pekanbaru City assisted by Spatial Planning and Building Office of Pekanbaru City which gives recommendations on the billboard point and 
other technical issues. In terms of surveillance and control, Regional Revenue Office of Pekanbaru City coordinate with Municipal Police of Pekanbaru City which conducting surveillance and control in the field until the demolition of billboard that violate the rules. By implementation of this model, be expected the presence of billboards in Pekanbaru City become well arranged, add to the visual beauty of the city as well as meet safety standards. Other than that, the billboard tax contributions to PAD of Pekanbaru City can also be increased.

\section{CONCLUSIONS}

Based on the identification of the problem, the results of research and discussion that has been described above, it can be concluded the following:

1. Implementation of policy for carrying out advertisement that runs in the city of Pekanbaru is still not effective due to lack of attention to standards and policy objectives ; resource; communication between related organizations; disposition / attitude implementers; as well as the economic environment, social, and political. Among the factors of policy implementation proposed by Van Meter and Van Horn, in this case the characteristics of the implementing organization is not proved instrumental in the implementation of policy implementation billboards in the city of Pekanbaru.

2. Factors that led to the implementation of planning policies billboards in the city of Pekanbaru yet effective, among others: (a) A portion of the apparatus do not understand the policy implementor policy objectives; (b) Lack of mental policy implementor of personnel resources; (c) agencies as a member of the Advertising Team implementor policy is not supported by automation technology resources as a whole; (d) communication is still not good, both among party leaders and subordinates, between departments as a member of Team Advertising implementor of policies, such Pekanbaru City Government with the mounting of billboards, as well as between the Government of Pekanbaru City with communities being targeted policies, especially those on roads that are free of billboards; (e) The existence of political pressure from certain parties to the implementor of policies; (f) The lack of decisiveness in implementing measures; (g) Pekanbaru City Government are inconsistent with the objectives of the policy administration billboards; and (h) There is overlap between the policy administration policies billboard with the Spatial Plan of existing City.

3. Model billboard implementation planning policies throughmodel approaches benchmarking and theories Van Mater and Van Horn ideal in the arrangement of billboards in the city of Pekanbaru Pekanbaru City Revenue mandated as the institution responsible for the implementation and structuring of billboards in the city of Pekanbaru. Revenue Authority of the City of Pekanbaru ranging from licensing, advertisement tax acceptance, supervision until demolition. In terms of licensing, assisted by Revenue Pekanbaru City Planning Office Building Pekanbaru City that provides recommendations regarding the point of billboards and other technical problems. In terms of supervision and control, in coordination with the Revenue Pekanbaru City Pekanbaru City municipal police who conduct surveillance and control in the field until the dismantling of billboards that violate the rules. This model was developed based on the results of benchmarking with Batam and Rokan Hilir and incorporates four (4) factors of the Theory of Policy Implementation and Van Meter and Van Horn is not optimal ie standard factors and policy objectives, implementation activities and communication between organizations, characteristics of the implementing agency / implementor and tendency (disposition) of the implementing / implementor. In addition, researchers also increase the factor of control that does not exist on the theory of Van Meter and Van Horn and community participation factor to overcome the weaknesses of the theory of Van Meter and Van Horn that is topdown. By implemented this model, it is expected the presence of billboards in the city of Pekanbaru be well ordered, adding to the visual beauty of the city and meet safety standards. In addition, tax revenues billboards in the city of Pekanbaru also be improved.

Based on the conclusions that have been stated above, it can be said to be $a$ novelty in this study departs from the weaknesses of the theory of policy implementation of Van Meter and Van Horn is not any element of oversight and involvement and participation in the community resulting in policy implementation are less controllable and less able to touch the needs, desire or public issues that must beresolved.

\section{Recommendations}

Based on the findings of research has been stated above, it may be advisable:

1. To Perwako No. 24 In 2013, containing more technical provisions, should be revised to further adjust the regulation, supervision and control of the billboard with the implementing agencies more firmly set the authority and responsibilities.

2. Pekanbaru City Government in order to implement an effective policy for carrying billboard with, it is advisable to do the things that must be done is: (a) Need to increase understanding of the policy implementor personnel policy goals; (b) Need mental development personnel resources policy implementor implementation of signage and narrow the opportunity to make a deviation; (c) should be applied to the automation technology as a whole in offices as a member of Team Advertising the implementor ofpolicies; (d) the need to improve the quality and intensity of communication and coordination, both between policy makers with policy 
implementor, between departments as a member of Team Advertising implementor of policies, interpersonal implementor of policies, as well as between the Government of Pekanbaru City with communities being targeted policies; (e) It should be the protection of personnel policy implementor in implementing policies that are not afraid of pressure from certain parties; (f) the need firmness Pekanbaru City Government against any infringers advertisement policy administration; (g) Pekanbaru City Government must be consistent with the policy objectives of the organization of billboards, not to just support the improvement of the advertisement tax revenue but ignoring public safety and the aesthetics of the city; (h) shall be performed in sync on all product policy issued by the City of Pekanbaru in order to avoid overlapping policies.

3. In order for the model established in this study provide input and recommendations to the Pekanbaru city government to revise the implementation arrangements billboards in the city of Pekanbaru to come.

4. Linked to the monitoring, it is recommended that Revenue and municipal police Pekanbaru City stricter in imposing sanctions or discipline-billboard advertisement that violates the rules.

5. Further to researchers who are interested in examining the topic of policy implementation advertisement implementation, it is advisable to study in other cities in Indonesia and compared with abroad, in order to obtain the formulation of policy for carrying out advertisement to increase revenue at the same time adds to the beauty of the city.

\section{REFERENCES}

[1] Arikunto, S. 2010. Manajeman Penelitia., Jakarta: Rineka Cipta

[2] Azad, Hamid Reza Lashgarian dan Boushehri, Nader Shetab. 2014. "Billboard Advertising Modeling". International Journal for Traffic and Transport Engineering, Vol. 4, No.2.

[3] Danisworo,Mohammad. 2013. http: //www. bergerilya_archieve. blogspot.com. Inovasi Media Ruang Luar, accessed by 8 March 2017.

[4] Imamura, Yuiko. 2015. Policy Implementation Studies in Japan. Tokyo: Winpec.

[5] Indriantoro, Nur dan Bambang Supomo. 2012. Metodologi Penelitian Bisnis Untuk Akuntansi dan Manajemen. Edisi Pertama. Yogyakarta: BPFE Yogyakarta.

[6] Muhharia, Dwi Agus. 2012. "Proses Implementasi Kebijakan Reklame di Kota Pontianak." Jurnal S-1 Ilmu Administrasi Negara. Vol. 1, No. 1.

[7] Miles, Matthew B. dan A. Michael Huberman. 1992. Analisis Data Kualitatif, (terj. Tjetjer Rohendi Rohidi). Jakarta: Penerbit Universitas Indonesia.

[8] Maman Surachman. 2010. Teknik Wawancara dalam Penelitian Ilmu Sosial. Jakarta: Rineka Cipta

[9] Moleong, Lexy. 2008. Metode Penelitian Kualitatif. Bandung: PT. Remaja Rosdakarya.

[10] Nasution, S. 2010. Metode penelitian naturalistic-kualitatif. Bandung: Tarsito.

[11] Singarimbun, Masri. 2002. Metode dan Proses Penelitian. Jakarta: LP3ES.

[12] Sugiyono. 2012. Metode Penelitian Kualitatif. Bandung: Alpha Betha.

[13] Umar, Zulkarnain. 2015. "Model Implementation City Government Policy of the Use to Location Arrangement Advertisement Room in the Kuala Lumpur City", International Journal of Scientific and Research Publications, Vol. 5, Issue 9, pp. 1-4.

[14] Venderbrehgt. 2010. "Community research methods.” New York: McGraw Hill. 